
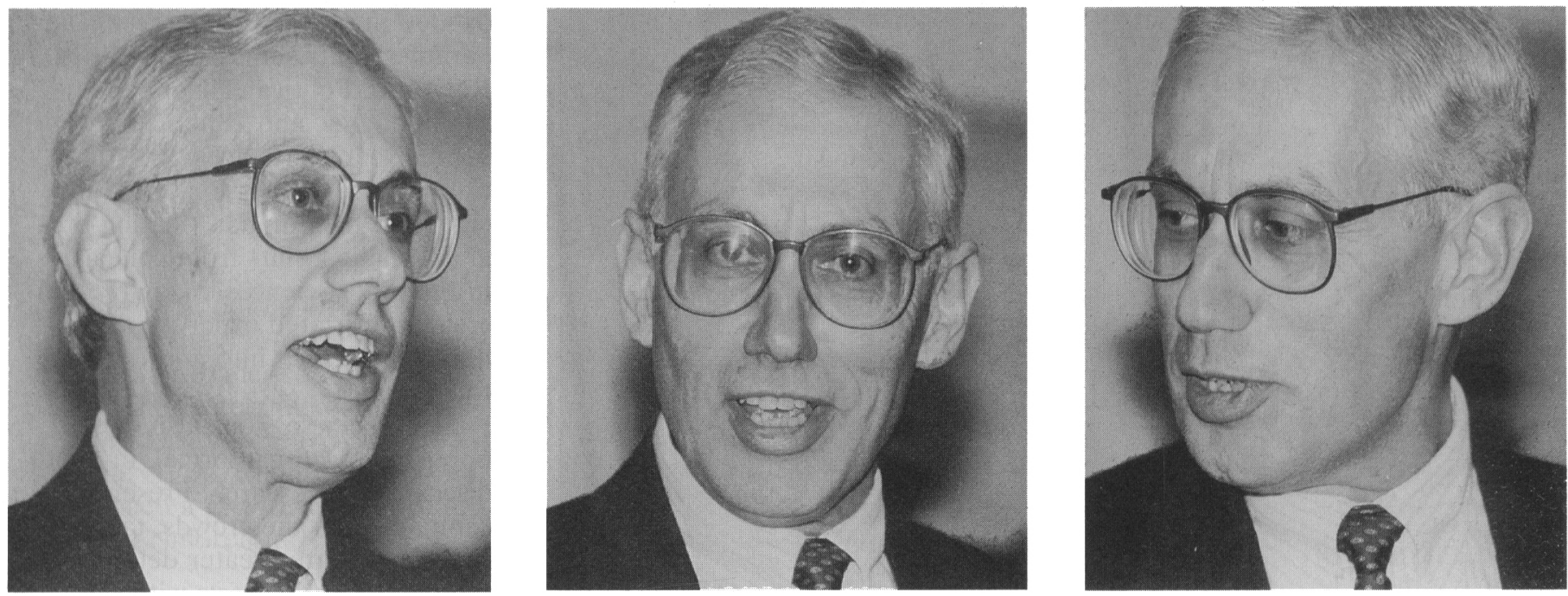

APSA President Arend Lijphart of the University of California, San Diego's Presidential Address, "Unequal Participation: Democracy's Unresolved Dilemma," will appear in the March 1997 issue of the American Political Science Review.

tics: Understanding Senate Voting on GATT and NAFTA in 1993-1994

Award Committee: Amy Bridges, University of California, San Diego, Chair; Paula D. McClain, University of Virginia; and Terry Moe, Stanford University.

The 1997 poster sessions will be organized by David Brady of Stanford University. Rules and guidelines for next year's presentations will be available in a subsequent issue of $P S$.

\section{Association Distributes Annual Awards}

The 1996 APSA Awards Ceremony, held August 30 in conjunction with the Annual Meeting, featured a slate of 18 awards, including the Association's highest honor, the James Madison Award. Former APSA president Philip Converse (1984-85), was selected winner of the triennial Madison Award honoring a career of scholarly excellence, including directorship of The Center for Advanced

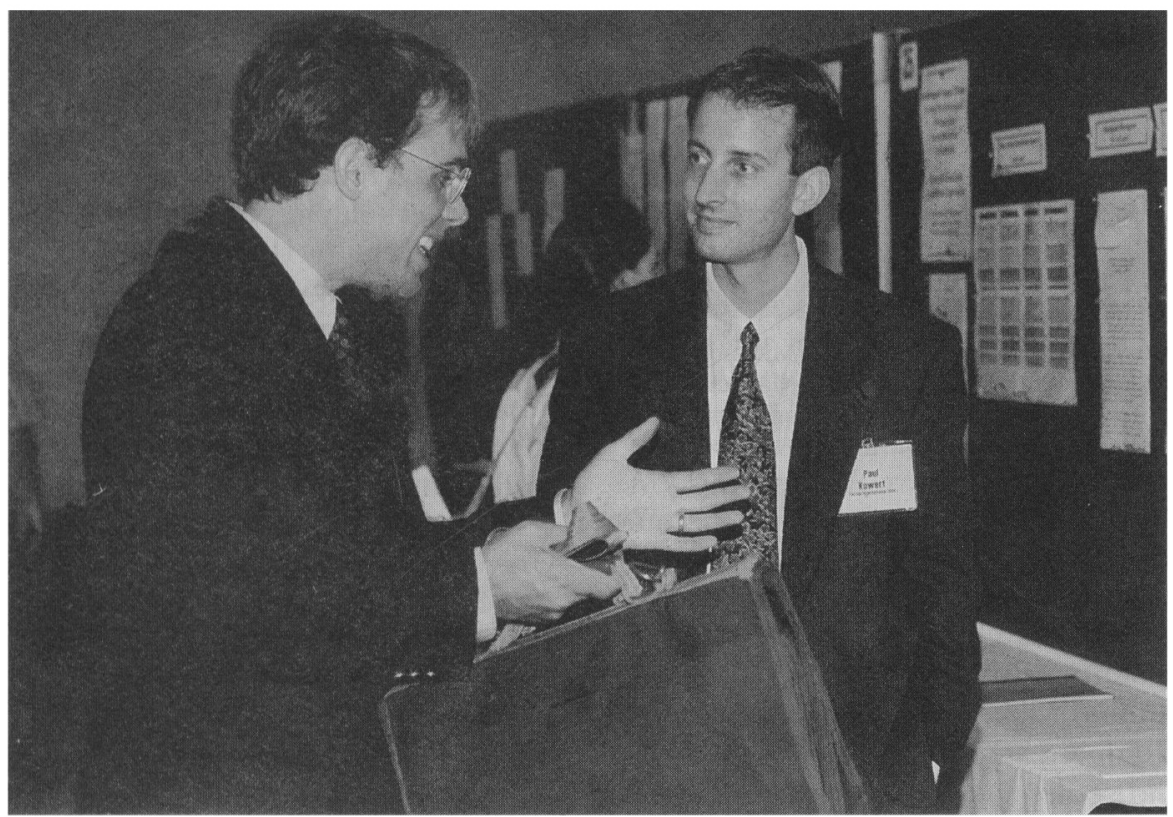

The Poster Session on Political Theory and Methodology. Paul Kowert [R], Florida International University, winner of the session's best poster award listens to comments on his presentation "The Political Personality: Q-Sort Profiles of Six Postwar American Presidents."
Study in the Behavorial Sciences. Madison Award Committee chair Edward Keller noted “... through his mastery of our discipline as author, teacher, mentor and colleague, (Converse) has made a remarkable scholarly contribution to the discipline." Earlier in the day Converse delivered the 1996 Madison Lecture, "The Advent of Polling and Political Representation." A printed version of the lecture can be found in this issue of $P S$.

The 1996 John Gaus Distinguished Lecturer Award was presented to Lynton K. Caldwell of Indiana University. The Gaus Award is presented annually to honor a lifetime of exemplary scholarship in the joint tradition of political science and public administration, and more generally, recognizes and encourages scholarship in public administration. "Trained as a political scientist, yet stimulated by interactions with other disciplines, Caldwell took the road less traveled and made himself an interdisciplinary scholar," said Gaus Committee Chair Rosemary O'Leary during her introduction of Caldwell at the lecture presentation. Caldwell's lecture, "The State as a Work of Art: Statecraft for the 21st Century," is featured in this issue of $P S$.

Nine young scholars were recognized at the Awards Ceremony for their outstanding dissertations completed during the 1994-95 academic years. Eight dissertation prizes were presented, including, the Gabriel A. 


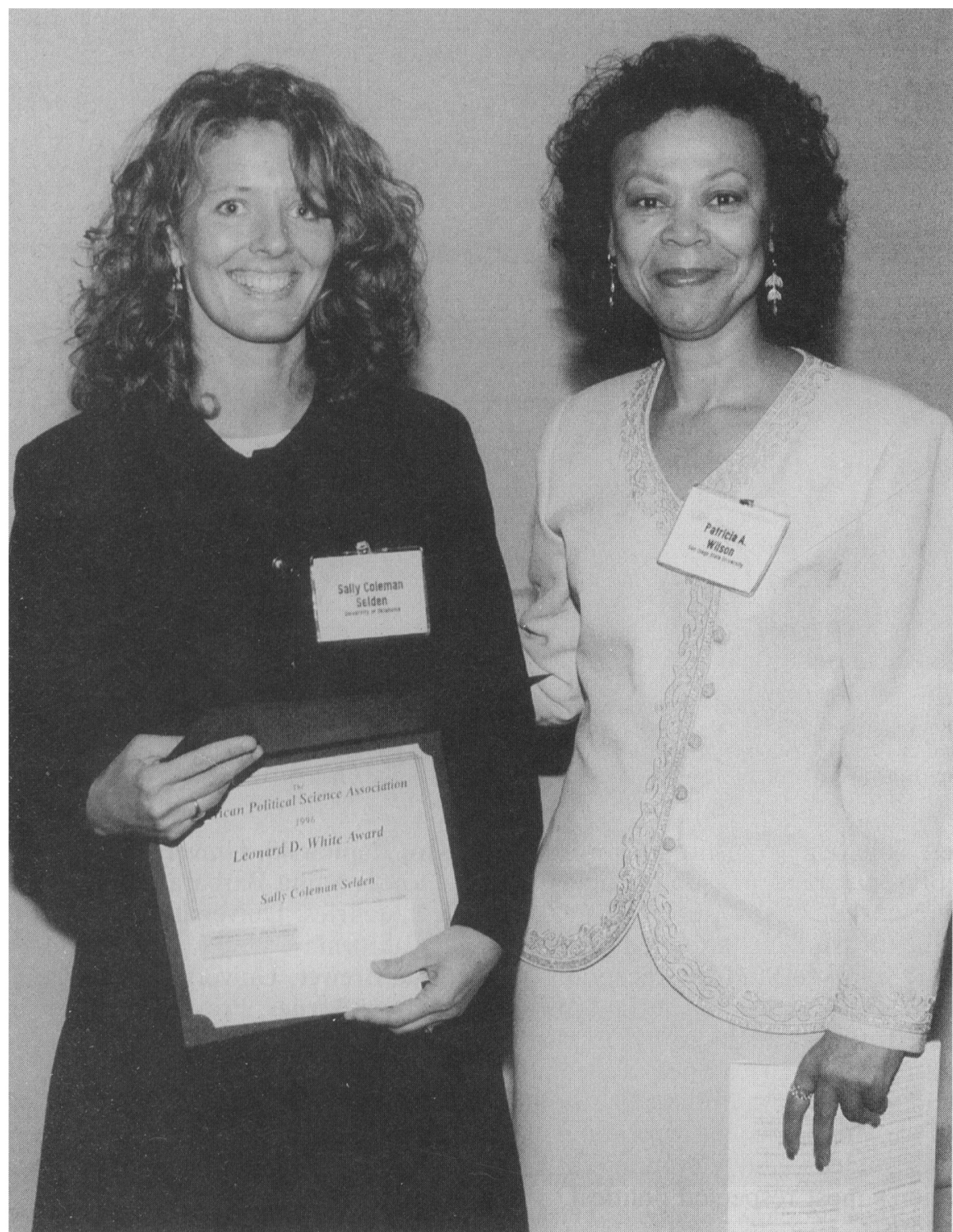

Sally Coleman Selden [L], University of Oklahoma, recipient of the Leonard D. White Dissertation Award in the field of public administration for her dissertation "Representative Bureaucracy: Examining the Potential for Administrative Responsiveness." Presenting the award, Patricia Wilson, San Diego State University, Award Committee Chair.

Almond Award to Torben Iversen, currently at Harvard University, for the best dissertation in comparative politics. Peter Lange of Duke University served as dissertation chair. Thomas M. Carsey, now at the University of Kansas, accepted the William Anderson Award in state and local politics. Gerald C. Wright, of Indiana University chaired his dissertation committee. Charles R. Epp, Indiana University, claimed the Edward C. Corwin Award in public law; Joel Grossman, University of Wisconsin-Madison served as dissertation chair. The Harold D. Lasswell Award in policy studies was pre- sented to Robert David English of Allegheny College; Stephen E. Cohen, Princeton University, was dissertation chair. Katherine Barbieri, currently at the University of North Texas, received the Helen Dwight Reid Award in international relations, law and politics. Stuart A. Bremer, SUNY-Binghamton served as dissertation chair. Co-winners Sarah Binder of the Brookings Institution and Patricia Conley of Northwestern University accepted the Schattschneider prize in American government and politics. Steven S. Smith, University of Minnesota, and Christopher Achen, University of
Chicago were their respective dissertation chairs. Completing the year's dissertation awards, the Leo Strauss Award in political philosophy was presented to Eyal Chowers, currently at Tel Aviv University. Charles Taylor and James Tully of McGill University served as dissertation chairs.

The annual Pi Sigma Alpha Franklin L. Burdette award for the best paper presented at the previous years annual meeting was presented to SUNY-Stony Brook faculty member Jeffrey Segal. Segal's 1995 paper "Marksist (and Neo-Marksist) models of Supreme Court Decision Making: Separation-of-Powers in the Positive Theory of Law and Courts," was also winner of the Law and Court Section's Best Faculty Paper Award. The 1996 Heinz Eulau Award Committee named "Dynamic Representation," by Robert Erikson, University of Houston, James A. Stimson, University of Minnesota, and Michael B. MacKuen, University of Missouri-St. Louis the best article published during 1995 in the American Political Science Review.

Book Award winners for 1996 included two Duke University faculty members. John Aldrich was presented with the Gladys M. Kammerer Award for the best book in the field of U.S. national policy for Why Parties? The Origin and Transformation of Political Parties in America (University of Chicago Press) and Herbert Kitschelt accepted the Woodrow Wilson Foundation Award for his book, The Radical Right in Western Europe (University of Michigan Press), the best book on government, politics or international affairs. Gwendolyn Mink, University of California-Santa Cruz, was selected as recipient of the 1996 Victoria Schuck Award for the best book on women and politics. Her book, The Wages of Motherhood: Inequality in the Welfare State, 1917-1942, was published by Cornell University Press. Lastly, the Ralph J. Bunche Award Committee named Will Kymlicka of the University of Ontario winner of the Bunche prize for his book Multicultural Citizenship: A Liberal Theory of Minority Rights (Oxford University Press).

The Hubert Humphrey Award, presented each year in recognition of notable public service by a political scientist, was awarded to Bruce 
C. Vladeck, Director, Health Care Financing Administration, U.S. Department of Health and Human Services. Vladeck received his Ph.D. in political science from the University of Michigan. Washington Post national correspondent E.J. Dionne was selected as winner of the 1996 Carey McWilliams Award honoring his contribution to our understanding of politics.

Details on awards presented by the Organized Sections appears later in Association News.

\section{APSA Welcomes Graduate Students at San Francisco Meeting}

Graduate students are an integral part of the APSA Annual Meeting, and this year over 1500 attended. Graduate students delivered papers in the approximately 650 panels and roundtables during the 1996 meeting, and could also be found among the 250 scholars presenting posters at the Annual Meeting poster sessions.

Several events and services targeted graduate students in San Francisco, including two forms of informal exchanges with senior scholars. "Breakfast with Champions" gave students the opportunity to participate in relaxed roundtable discussions with renowned political scientists. Discussions ranged from career planning and networking relationships, to balancing family responsibilities, formulating research, and improvements in teaching skills.

At the Annual Meeting's Leading Scholar series, the graduate students participated in roundtable sessions with two legendary scholars. Gabriel A. Almond and Heinz Eulau, both of Stanford University and both former APSA presidents, discussed the evolution of political science, and the controversies that have reconstructed the discipline in recent decades.

The Professional Placement Service, located in the Hotel Nikko San Francisco, attracted over 600 applicants. The Service offers an opportunity for institutions to meet job candidates face-to-face and discuss prospective employment opportuni-

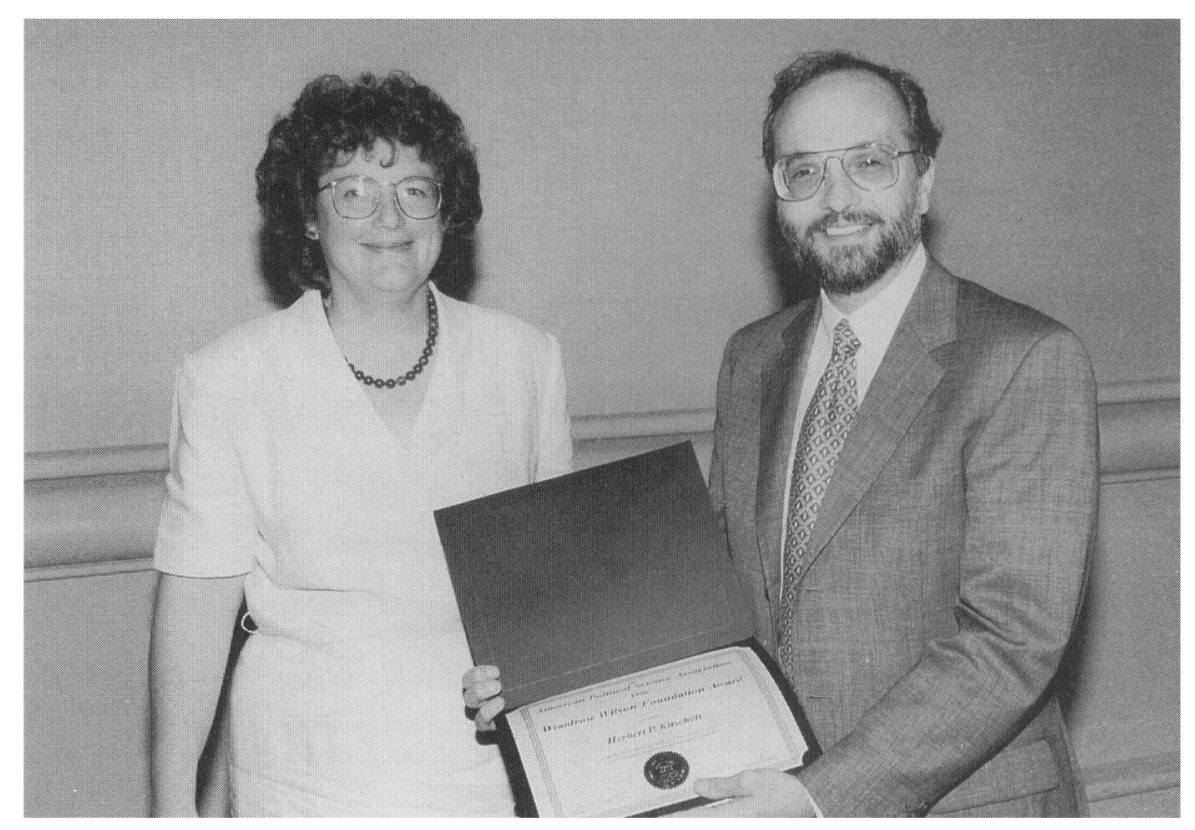

Herbert Kitschelt, Duke University, receives the Woodrow Wilson Foundation Award for the best book published in 1995 on government, politics, or international affairs. Title of his book: The Radical Right in Western Europe (University of Michigan Press). Presenting the award is Virginia Sapiro, University of Wisconsin-Madison, Award Committee Chair.

ties. This year 96 institutions were represented and 177 job openings were posted.

Finally, students attended the Annual Graduate Student Reception, where they received a special welcome from President Arend Lijphart and President-Elect Elinor Ostrom. Held at the Crowne Plaza Parc Fifty-Five Hotel, students mingled with other students and with many of the nation's most respected political scientists.

\section{APSA Awards Advanced Graduate Student Travel Grants}

In a continuing effort to assist graduate students slated to present papers at the annual meeting, the Association again offered its Advanced Graduate Student Travel Grant Program. With funding through the APSA Council, 18 travel grants were awarded. Nearly 90 applications were submitted. The names and affiliations of winners follow:

Russell Lightfoot, Miami University Tom Lewis, University of Washington

Steven Lobell, University of California-Los Angeles
Kira Poplowski, University of California-Santa Barbara

J. L. Jeffries, University of Southern California

Gene Brewer, University of Georgia Andrew Barnes, Princeton University Jeff J. Corntassel, University of Arizona

Patrice M. Mareschal, University of Oklahoma

Scott H. Huffmon, University of Mississippi

Peter Stone, University of Rochester

Robert H. Bruhl, University of Illinois at Chicago

Janice M. Googin, Brown University Marie Gottschalk, Yale University

Paul G. Harris, Brandeis University

Paul A. Harris, Auburn University

Heather Trippel, Purdue University

Douglas M. Gibler, Vanderbilt University

\section{Annual Meeting Short Courses Promote Professional Development}

Ten short courses were offered in San Francisco the day before this year's Annual Meeting began. As part of the Annual Meeting's "Professional Day" program, several APSA Organized Sections and the National Issues Forum sponsored 